THE ANTIGENIC DIFFERENTIATION OF SEVEN STRAINS OF MYCOPLASMA HYORHINIS BY GROWTH-INHIBITION, METABOLISM - INHIBITION, LATEX - AGGLUTINATION, AND POLYACRYLAMIDE-GEL-ELECTROPHORESIS TESTS

\author{
M. Golš, ${ }^{*}$ F. KuKSa, ${ }^{*}$ J. Franz* and D. TAYlor-Robinson $\dagger$ \\ The Veterinary Research Institute, Brno, Czechoslovakia, ${ }^{*}$ and Clinical Research Centre, \\ Watford Road, Harrow, Middlesex HAI 3UJ, England $\dagger$
}

\title{
Plate IV
}

IN recent years the identification and classification of mycoplasmas has become increasingly dependent on serological tests because these may distinguish between mycoplasma species and also provide evidence for the existence of serologically heterogeneous strains within a mycoplasma species.

Serological heterogeneity among Mycoplasma hominis strains was demonstrated by agglutination (Nicol and Edward, 1953), complement-fixation and gel-diffusion (Taylor-Robinson et al., 1963), and metabolism-inhibition techniques (Purcell et al., 1967). Similarly, minor serological differences were detected among $M$. gallisepticum strains by Taylor-Robinson and Berry (1969) who used the metabolism-inhibition test. Antigenic variants have also been described for $M$. arthritidis (Lemcke, 1964) and for $M$. pulmonis (Leach and Butler, 1966). Furthermore, Deeb and Kenny (1967) considered that the heatstable complement-fixing and precipitating antigen they found in $M$. pulmonis strains was subtype-specific.

In contrast, by employing the metabolism-inhibition test, which appears to be one of the most sensitive methods for measuring minor antigenic differences in the same species, no significant differences were found among strains of $M$. orale type $1, M$. orale type $2, M$. salivarium or $M$. hyorhinis (Purcell et al., 1967). More recently, the close relationship among strains of $M$. hyorhinis shown by the metabolism-inhibition test was confirmed, but growth of some of the strains was not prevented by antisera in the disk growth-inhibition test (Dinter and Taylor-Robinson, 1969); these findings were interpreted as indicating the existence of strains that were sensitive and strains that were insensitive to antibody.

In the present study seven strains of $M$. hyorhinis isolated in various countries have been examined by metabolism-inhibition, growth-inhibition and latex-agglutination tests to detect serological differences among them or the above-mentioned phenomenon of serological non-reactivity. Although the strains were not serologically distinct from one other, rather striking evidence of serological heterogeneity is presented which suggests that the species $M$. hyorhinis might be divided into subtypes.

Received 5 Feb. 1973; accepted 4 June 1973.

J. MED. MICROBIOL.-VOL. 7 (1974) 


\section{MATERIALS AND METHODS}

Mycoplasma strains. The $M$. hyorhinis strains that were examined are listed in table I. Each strain was purified by four successive subcultures from a single colony.

Culture medium. Use was made of a single type of medium, the composition of which was as follows: $40 \%$ (v/v) Hanks' solution, 20\% (v/v) unheated horse serum, $20 \%$ (v/v) extract of fresh baker's yeast, $20 \%$ (v/v) beef heart infusion, $1.0 \%$ (w/v) glucose, $0.005 \%(\mathrm{w} / \mathrm{v})$ thallium acetate, $0.002 \%(\mathrm{w} / \mathrm{v})$ phenol red, and $1000 \mathrm{IU}$ penicillin per $\mathrm{ml}$. The $p \mathrm{H}$ was adjusted to $7 \cdot 7-7 \cdot 8$. Solid medium consisted of liquid medium with the addition of $1.0 \%$ Difco Noble Agar.

Antigen preparation. Organisms propagated by aerobic incubation of liquid medium at $37^{\circ} \mathrm{C}$ were centrifuged at $10,500 \mathrm{~g}$ for $30 \mathrm{~min}$. The pellets were rinsed three times with saline and subsequently resuspended in saline to $1 / 100$ of their original volume. The antigens were stored at $-70^{\circ} \mathrm{C}$.

TABLE I

Mycoplasma hyorhinis strains isolated from pigs

\begin{tabular}{|c|c|c|c|}
\hline Strain & $\begin{array}{c}\text { Strain } \\
\text { isolated } \\
\text { from }\end{array}$ & $\begin{array}{l}\text { Geographical } \\
\text { source of } \\
\text { strain }\end{array}$ & Strain supplied by \\
\hline \multirow{2}{*}{$\begin{array}{l}\text { NE110 } \\
\text { Ni6 } \\
\text { Tr32 } \\
\text { S218 }\end{array}$} & \multirow{2}{*}{$\begin{array}{l}\text { Lungs } \\
\text { Lungs } \\
\text { Lungs } \\
\text { Nasal cavity }\end{array}$} & \multirow{2}{*}{$\begin{array}{l}\text { Czechoslovakia } \\
\text { Czechoslovakia } \\
\text { Czechoslovakia } \\
\text { England }\end{array}$} & \multirow{5}{*}{$\begin{array}{l}\text { Dr M. Goǐs, Veterinary Research } \\
\text { Institute, Brno, Czechoslovakia } \\
\text { Dr M. Gois, Royal Veterinary College, } \\
\text { London, England } \\
\text { Dr J. Akkermans, Central Veterinary } \\
\text { Institute, Rotterdam, Holland } \\
\text { Dr Z. Dinter, The Wallenberg Labora- } \\
\text { tory, University of Uppsala, Sweden } \\
\text { Dr W. P. Switzer, Iowa State University, } \\
\text { Ames, USA }\end{array}$} \\
\hline & & & \\
\hline Hers & Brain & Holland & \\
\hline $\mathbf{K}$ & Nasal cavity & Sweden & \\
\hline 7 & Nasal cavity & USA & \\
\hline
\end{tabular}

Preparation of antisera. Young adult rabbits were immunised as follows: a mixture of $1.0 \mathrm{ml}$ of antigen and $1.0 \mathrm{ml}$ of Freund's complete adjuvant was inoculated intramuscularly into one thigh and 3 weeks later the same volume was given in the other thigh. After another 3 weeks $1 \cdot 0-\mathrm{ml}$ doses of antigen were administered intravenously at 4- to 6-day intervals. Five days after the last inoculation (about 15 doses) the rabbits were exsanguinated and the sera stored at $-20^{\circ} \mathrm{C}$. Sera pooled from two immune rabbits were used in the tests.

Growth-inhibition (GI) test. The method of Clyde (1964) was used. Several decimal dilutions of stock mycoplasma cultures were inoculated on agar medium and then filter-paper disks, $5.5 \mathrm{~mm}$ in diameter soaked with $0.025 \mathrm{ml}$ of undiluted antiserum, were placed on the agar. The inhibition zone was measured from the edge of the disk to the commencement of colonies, and only zones greater than $1.0 \mathrm{~mm}$ were regarded as significant. The results were usually read after 72 hours' incubation.

Metabolism-inhibition (MI) test. Modification of the method described by TaylorRobinson et al. (1966) was mentioned in detail previously (Goiš, 1968). The antiserum titre was expressed as the highest dilution that prevented the $p \mathrm{H}$ of the medium, originally $7 \cdot 8$, from decreasing below 7.2; at the same time the $p \mathrm{H}$ of antiserum-free medium that contained organisms decreased to about 6.5. Guinea-pig serum was not used.

Latex-agglutination $(L A)$ test. The procedure described by Morton (1966) was followed with some minor modifications. Glycine-buffered saline (GBS) of $p \mathrm{H} 8.2$ and latex particles were obtained from Immuna, Sarišské Michalany. Carrier latex particles of $0.02 \mu \mathrm{m}$ were diluted 1 in 5 with distilled water. The cultures of mycoplasmas were harvested by centrifugation ( $30 \mathrm{~min}$. at $10,500 \mathrm{~g}$ ) after 24 to 48 hours' incubation at $37^{\circ} \mathrm{C}$. The centrifuged cells 
were resuspended in GBS to produce suspensions of $\mathbf{5 0}$ turbidity units as recorded in a Pulfrich photocolorimeter (Elfo). One millilitre of each suspension was mixed with $0.4 \mathrm{ml}$ latex and after $10 \mathrm{~min}$. at room temperature, $8.6 \mathrm{ml}$ GBS containing a 1 in 1000 dilution of normal rabbit serum was added. After another $10 \mathrm{~min}$. the antigen was ready to use. As was determined by box titration, 1 in 2 or 1 in 4 dilutions of antigen were used as a routine. Hyperimmune rabbit sera were inactivated for $30 \mathrm{~min}$. at $56^{\circ} \mathrm{C}$. Antigens and sera were used in $0.25-\mathrm{ml}$ volumes. The tests were incubated for 2 hours at $42^{\circ} \mathrm{C}$ in a waterbath and then the tubes were centrifuged for about $10 \mathrm{~min}$. at 2000 r.p.m. An arbitrary +2 to +4 agglutination reaction was recorded as positive.

Polyacrylamide-gel electrophoresis. The procedure described by Rottem and Razin (1967) was followed with minor modifications. Cell proteins were dissolved in phenol-acetic acid-water $(2: 1: 5 \cdot 5, \mathrm{w} / \mathrm{v} / \mathrm{v})$ and run in polyacrylamide gels at room temperature for about 2 hours at a constant current of $5 \mathrm{~mA}$ per tube.

Antibody (titre) ratio. Calculations of antibody (titre) ratios have been described previously by Archetti and Horsfall (1950). The geometric mean of the ratios is given by the formula $r=\sqrt{r_{1} \times r_{2}}$ where

$$
\begin{aligned}
& r_{1}=\frac{\text { heterologous titre }}{\text { homologous titre }} \frac{\text { (mycoplasma 2) }}{\text { (mycoplasma 1) }} \\
& r_{2}=\frac{\text { heterologous titre }}{\text { homologous titre }} \frac{(\text { mycoplasma 1) }}{\text { (mycoplasma 2) }}
\end{aligned}
$$

Value $r$ gives, as a single figure, the extent of an antigenic difference between two mycoplasmas and their antisera in cross-serological reactions.

Statistical analysis by the coefficient of concordance. Sets of antibody (titre) ratios obtained from GI, MI and LA tests were statistically calculated by concordance coefficient $W$ according to the method of Kendall (1948) as modified by Malý (1957). The measure of the degree of concordance was computed by the formula:

$$
\frac{12\left(S_{w}-1\right)}{m^{2}\left(n^{2}-1\right) n+24}
$$

where: $S_{w}=$ the sum of squares of $d$ values $\left(\Sigma d^{2}\right) ; d$ is obtained by subtraction of the mean computed by the formula $\frac{1}{2} m(n+1)$ from the sum of ranking in GI, MI and LA tests for each strain in the column (see table VI); $m=$ number of methods applied for serological analysis; $n=$ number of strains compared.

Statistical analysis by the rank correlation coefficient. Analyses of antibody (titre) ratios of the three pairs of tests, GI-MI, GI-LA, and MI-LA, were calculated using the rank correlation coefficient $\left(r_{8}\right)$ described by Spearman (1904). Rank values of two tests were computed by the formula:

$$
r_{s}==1-\frac{6 \Sigma d^{2}}{n\left(n^{2}-1\right)}
$$

where $d^{2}$ is the sum of squares of the values obtained by subtraction of ranked pair values and $n=$ number of strains compared.

\section{RESULTS}

\section{The relationship between strains of Mycoplasma hyorhinis}

GI tests. The results presented in table II were calculated from the mean width of zones obtained in five replicate tests. In all tests, several dilutions of each strain were used, so that it was possible to measure only zones that developed on plates where the number of colonies reached 2-7 thousand per plate. By this procedure the sizes of zones recorded for a particular strain remained 
almost constant, and relatively low values of standard deviation appeared to correlate with small variations of zone sizes observed in individual tests.

TABLE II

Inhibition of growth of seven Mycoplasma hyorhinis strains by their rabbit antisera

\begin{tabular}{|c|c|c|c|c|c|c|c|}
\hline \multirow{2}{*}{ Strains } & \multicolumn{7}{|c|}{$\begin{array}{c}\text { Mean width* }(\mathrm{mm}) \text { of growth-inhibition zones produced by rabbit antisera } \\
\text { prepared against strains }\end{array}$} \\
\hline & Nel10 & Ni6 & $\operatorname{Tr} 32$ & S218 & Hers & $\mathbf{K}$ & 7 \\
\hline $\begin{array}{l}\text { Ne110 } \\
\text { Ni6 } \\
\text { Tr32 } \\
\text { S218 } \\
\text { Hers } \\
\text { K } \\
7\end{array}$ & $\begin{array}{l}4.1( \pm 1.0 \dagger) \\
1.1( \pm 0.7) \\
1.5( \pm 0.9) \\
1.3( \pm 0.3) \\
2.4( \pm 0.7) \\
0.8( \pm 0.3) \\
1.6( \pm 0.5)\end{array}$ & $\begin{array}{l}0.5( \pm 0.0) \\
5.4( \pm 1.0) \\
4.7( \pm 1.4) \\
0.8( \pm 0.5) \\
1.2( \pm 0.3) \\
1.0( \pm 0.3) \\
0.4( \pm 0.2)\end{array}$ & $\begin{array}{l}1.9( \pm 0.2) \\
5.4( \pm 0.6) \\
6.2( \pm 0.9) \\
0.8( \pm 0.3) \\
1.5( \pm 1.1) \\
1.3( \pm 0.8) \\
2.3( \pm 0.3)\end{array}$ & $\begin{array}{l}2.1( \pm 0.5) \\
1.6( \pm 0.6) \\
2.4( \pm 1.0) \\
3.6( \pm 0.6) \\
2.0( \pm 0.3) \\
2.5( \pm 0.2) \\
0.6( \pm 0.2)\end{array}$ & $\begin{array}{l}2.1( \pm 0.7) \\
2.9( \pm 0.9) \\
2.9( \pm 1.0) \\
1.8( \pm 0.7) \\
4.2( \pm 1.3) \\
1.2( \pm 0.6) \\
2.5( \pm 0.5)\end{array}$ & $\begin{array}{l}0.3( \pm 0.3) \\
2.7( \pm 0.9) \\
2.5( \pm 0.8) \\
0.3( \pm 0.3) \\
1.0( \pm 0.5) \\
3.0( \pm 1.4) \\
0.6( \pm 0.4)\end{array}$ & $\begin{array}{l}1.2( \pm 0.3) \\
0.5( \pm 0.0) \\
0.3( \pm 0.3) \\
1.2( \pm 0.9) \\
1.8( \pm 0.5) \\
0.6( \pm 0.4) \\
2.5( \pm 0.8)\end{array}$ \\
\hline
\end{tabular}

* Calculated from five replicate tests. † Standard deviation.

It is apparent that each of the seven strains was inhibited most effectively by the homologous antiserum. A close reciprocal relationship was shown for strains Ni6 and $\operatorname{Tr} 32$. Comparatively slight cross-reaction was shown by the pairs of strains Ne110-7, S218-7 and Hers-K and that shown by the pair Ne110-Ni6 was even less. Cross-reactions were not apparent between strain

TABLE III

Inhibition of metabolism of seven Mycoplasma hyorhinis strains by their rabbit antisera

\begin{tabular}{|c|c|c|c|c|c|c|c|}
\hline \multirow{2}{*}{ Strains } & \multicolumn{7}{|c|}{ Titres* of rabbit antisera prepared against strains } \\
\hline & Ne110 & Ni6 & $\operatorname{Tr} 32$ & S218 & Hers & $\mathbf{K}$ & 7 \\
\hline $\begin{array}{l}\text { Ne110 } \\
\text { Ni6 } \\
\text { Tr32 } \\
\text { S218 } \\
\text { Hers } \\
\text { K } \\
7\end{array}$ & $\begin{array}{r}640 \\
40 \\
80 \\
80 \\
80 \\
40 \\
160\end{array}$ & $\begin{array}{r}<20 \\
5120 \\
320 \\
40 \\
80 \\
80 \\
40\end{array}$ & $\begin{array}{r}160 \\
1280 \\
1280 \\
160 \\
320 \\
80 \\
160\end{array}$ & $\begin{array}{r}80 \\
80 \\
160 \\
640 \\
80 \\
160 \\
160\end{array}$ & $\begin{array}{r}80 \\
80 \\
320 \\
320 \\
640 \\
160 \\
160\end{array}$ & $\begin{array}{r}<20 \\
160 \\
160 \\
320 \\
160 \\
640 \\
160\end{array}$ & $\begin{array}{r}80 \\
40 \\
40 \\
80 \\
160 \\
<20 \\
\mathbf{1 2 8 0}\end{array}$ \\
\hline
\end{tabular}

* Each titre represents the geometric mean of four replicate tests.

$\operatorname{Tr} 32$ and antiserum to 7, or between strain S218 and antiserum to Ni6, $\operatorname{Tr} 32$ and $\mathrm{K}$. Reciprocally negative reactions were found between the pairs $\mathrm{Ne} 110-\mathrm{K}$, Ni6-7 and K-7, though some sera strongly inhibited their homologous strains (Ne110, Ni6).

MI tests. The MI titres shown in table III are the geometric means of four replicates tests, although the titres obtained in individual tests were closely similar. As in the GI test, homologous reactions, though varying somewhat in 
their magnitude, were generally greater than heterologous ones. Thus, antiserum to strain Ni6 inhibited at a dilution of 5120 the metabolism of the homologous strain, whereas in tests with heterologous strains it did so only at dilutions of $320-<20$.

It is also apparent from table III that reactions between strains were sometimes negative $(<20)$ in one direction. Thus, the metabolism of strain Ne110 was not inhibited by antisera to Ni6 and K, and also the metabolism of strain K was not inhibited by antiserum to strain 7 . The poor cross-reactivity shown by the pairs of strains Ne110-Ni6, Ne110-K, Ni6-7, and Ni6-S218, suggested no more than a slight antigenic relationship.

$L A$ tests. In preliminary experiments the specificity of the LA test was examined by testing $M$. hyorhinis against $M$. granularum and $M$. hyopneumoniae.

TABLE IV

Latex-agglutination tests with seven Mycoplasma hyorhinis strains and their rabbit antisera

\begin{tabular}{l|rrrrrrrr}
\hline \multirow{2}{*}{ Strains } & \multicolumn{8}{|c}{ Titres* of rabbit antisera prepared against strains } \\
\cline { 2 - 8 } & Ne110 & Ni6 & Tr32 & S218 & Hers & K & 7 \\
\hline Ne110 & & & & & & & & \\
Ni6 & $\mathbf{6 4 0}$ & 80 & 80 & 160 & 80 & 80 & 40 \\
Tr32 & 80 & $\mathbf{1 2 8 0}$ & 320 & 80 & 320 & 320 & $<20$ \\
S218 & 40 & 320 & $\mathbf{1 2 8 0}$ & 80 & 160 & 160 & 40 \\
Hers & 40 & 40 & 160 & $\mathbf{6 4 0}$ & 160 & 20 & $<20$ \\
K & 320 & 20 & 40 & 160 & $\mathbf{1 2 8 0}$ & 80 & 20 \\
7 & $<20$ & 40 & $<20$ & $<20$ & 320 & $\mathbf{6 4 0}$ & 80 \\
& 80 & 20 & 160 & 40 & 160 & 80 & $\mathbf{3 2 0}$ \\
\hline
\end{tabular}

* Each titre represents the geometric mean of four or five replicate tests.

Cross-reactions were not observed. As in MI tests, the titres obtained for different strains of $M$. hyorhinis represented the geometric mean of the results of 4-5 replicate tests (table IV). Homologous titres varied from 320 to 1280 and, as in the MI test, heterologous titres were always lower. Rather poor reactivity was shown by strain $\mathrm{K}$ which was not agglutinated by three heterologous antisera when they were diluted 1 in 20 . Antiserum to strain 7, which was less potent than the other antisera, either did not react at a dilution of 1 in 20 or reacted in low dilutions only with five of the six heterologous strains.

These results provide further confirmation of rather striking antigenic differences between some strains of M. hyorhinis.

\section{Polyacrylamide gel electrophoresis}

Electrophoresis of cell proteins produced essentially the same basic pattern for all seven strains (figure) and thus the method failed to reveal small differences in the protein composition of the cells that had easily been detected serologically. 


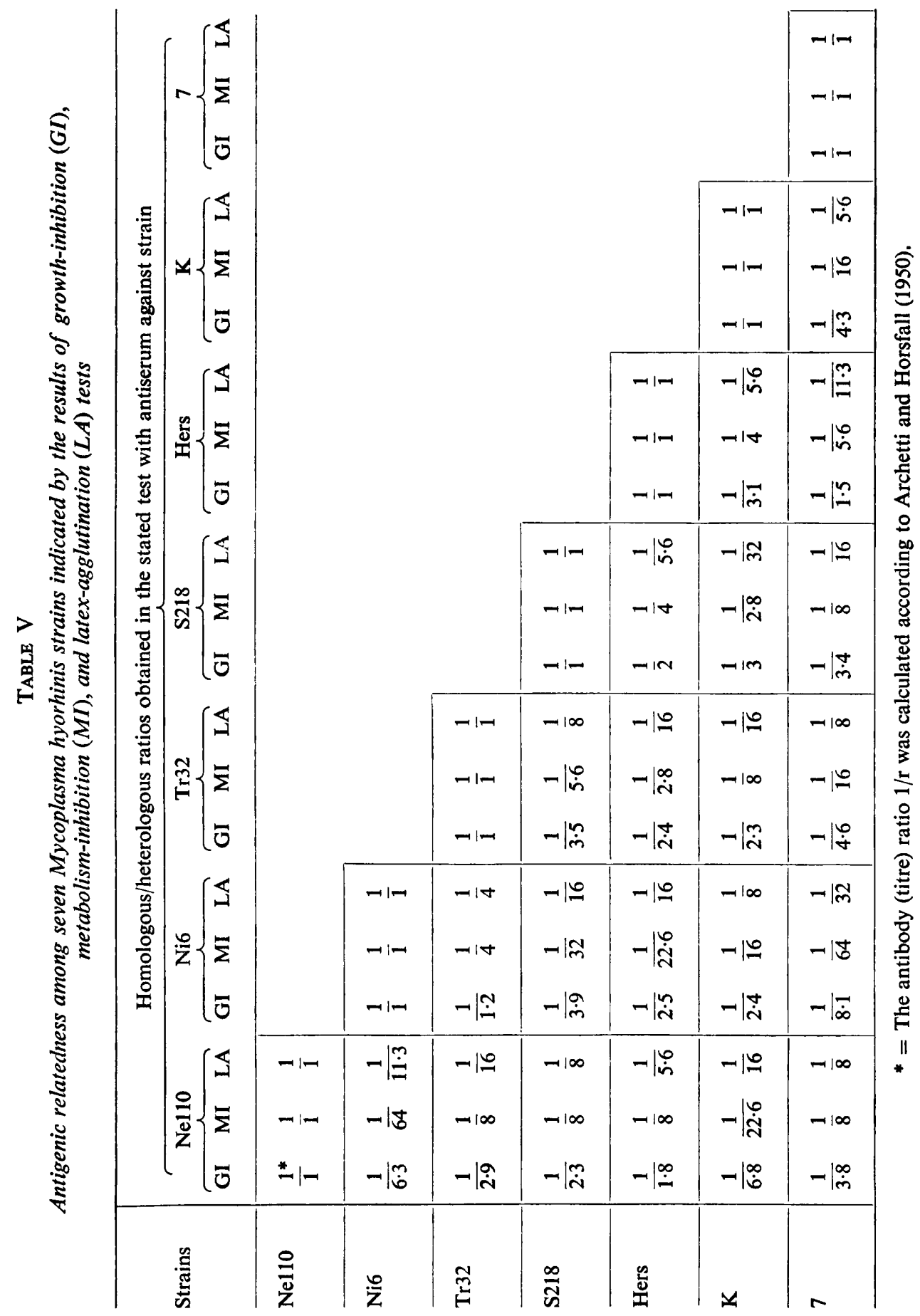


Statistical analysis of the results

An attempt was made to interpret antigenic relatedness in terms of the antibody ratio. As can be seen from table $\mathrm{V}$, the homologous ratio is by definition $1 / 1$ in all instances. The magnitude of the antigenic difference between

TABLE VI

Rank order of antibody (titre) ratios obtained in growth-inhibition (GI), metabolism-inhibition $(M I)$ and latex-agglutination $(L A)$ tests

\begin{tabular}{|c|c|c|c|c|c|c|c|c|c|c|}
\hline \multirow{3}{*}{ Strains } & \multicolumn{10}{|c|}{ Rankings of antibody (titre) ratios obtained in tests with antiserum against } \\
\hline & Ne110 & \multicolumn{3}{|c|}{ Ni6 } & \multicolumn{2}{|c|}{$\operatorname{Tr} 32$} & S218 & Hers & $\mathbf{K}$ & 7 \\
\hline & GI MI LA & GI & MI LA & & GI MI & LÀ & GI MI LA & GI MI LA & GI MI LA & GI MI LÀ \\
\hline $\mathrm{Ne} 110$ & $1^{*} \frac{1}{3 \dagger} 1$ & 6 & $\begin{array}{r}6.54 \\
16.5\end{array}$ & & $\begin{array}{rr}5 & 5.5 \\
16.5\end{array}$ & 6 & $\begin{array}{lll}3 & 5 \cdot 5 & 3 \cdot 5 \\
12 & \end{array}$ & $\begin{array}{lrl}3 & 6 & 3 \\
& 12 & \end{array}$ & $\begin{array}{lcc}7 & 7 & 5.5 \\
19.5 & \end{array}$ & $\begin{array}{ccc}3 & 3.5 & 3.5 \\
10 & \end{array}$ \\
\hline Ni6 & $\begin{array}{rrr}6 & 7 & 5 \\
& 18 & \end{array}$ & 1 & $\begin{array}{l}1 \\
3\end{array}$ & & $\begin{array}{ll}2 & 3 \\
7\end{array}$ & 2 & $\begin{array}{lc}7 & 7 \\
19 \cdot 5 & 5 \cdot 5\end{array}$ & $\begin{array}{lc}6 & 7 \\
19 \cdot 5 & 6 \cdot 5\end{array}$ & $\begin{array}{lr}35.5 & 4 \\
12.5 & \end{array}$ & $\begin{array}{lrl}7 & 7 & 7 \\
& 21 & \end{array}$ \\
\hline $\operatorname{Tr} 32$ & $\begin{array}{lll}5 & 3.5 & 6.5 \\
15 & \end{array}$ & 2 & $\begin{array}{l}2 \\
6\end{array}$ & & $\begin{array}{ll}1 & 1 \\
& 3\end{array}$ & 1 & $5 \underset{12 \cdot 5}{4}{ }^{3 \cdot 5}$ & $5 \underset{13.5}{2} 6 \cdot 5$ & $2{ }_{11.5}^{4} 5 \cdot 5$ & 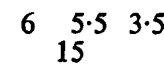 \\
\hline S218 & $\begin{array}{lll}4 & 3.5 & 3.5 \\
11 & \end{array}$ & & $\underset{15.5}{5} 5$ & & $\begin{array}{cc}6 & 4 \\
& 13 \cdot 5\end{array}$ & $3 \cdot 5$ & $\begin{array}{lll}1 & 1 & 1 \\
& 3 & \end{array}$ & $4 \begin{array}{rr}3.5 & 3 \\
10.5 & \end{array}$ & $\begin{array}{lrl}5 & 2 & 7 \\
& 14 & \end{array}$ & $\begin{array}{rr}3 \cdot 5 & 6 \\
13 \cdot 5 & \end{array}$ \\
\hline Hers & $\begin{array}{lll}2 & 3.5 & 2 \\
& 7.5 & \end{array}$ & & $\begin{array}{c}4 \\
13 \cdot 5\end{array}$ & & $\begin{array}{lr}4 \quad 2 \\
12\end{array}$ & 6 & $\begin{array}{lll}2 & 3 & 2 \\
& 7 & \end{array}$ & $\begin{array}{lll}1 & 1 & 1 \\
& 3 & \end{array}$ & $\begin{array}{lll}4 & 3 & 2.5 \\
& 9.5\end{array}$ & $\begin{array}{lll}2 & 2 & 5 \\
& 9 & \end{array}$ \\
\hline $\mathbf{K}$ & $7 \underset{19 \cdot 5}{6} 6 \cdot 5$ & 3 & $\begin{array}{ll}3 & 3 \\
9 & \end{array}$ & & $\begin{array}{lr}3 & 5.5 \\
& 14.5\end{array}$ & & $\begin{array}{lrl}6 & 2 & 7 \\
& 15 & \end{array}$ & $\begin{array}{rr}7 & 3.5 \\
13.5 & 3\end{array}$ & $\begin{array}{lll}1 & 1 & 1 \\
& 3 & \end{array}$ & $\begin{array}{lrl}5 & 5.5 & 2 \\
12.5 & \end{array}$ \\
\hline 7 & $\begin{array}{ccc}3 & 3 \cdot 5 & 3 \cdot 5 \\
10 & \end{array}$ & & $\begin{array}{r}6 \cdot 5 \quad 7 \\
20 \cdot 5\end{array}$ & & $\begin{array}{cc}7 & 7 \\
& 17 \cdot 5\end{array}$ & $3 \cdot 5$ & $\begin{array}{ccc}4 & 5 \cdot 5 & 5 \cdot 5 \\
& 15 & \end{array}$ & $\begin{array}{lrl}2 & 5 & 5 \\
& 12 & \end{array}$ & $\begin{array}{lll}6 & 5 \cdot 5 & 2 \cdot 5 \\
14 & \end{array}$ & $\begin{array}{lll}1 & 1 & 1 \\
& 3 & \end{array}$ \\
\hline $\begin{array}{l}\text { Rank } \\
\text { concor- } \\
\text { dance } \\
\text { coeff- } \\
\text { cient } \\
(W)\end{array}$ & 0.803 & & $0 \cdot 902$ & & 0.64 & & 0.706 & 0.566 & 0.594 & 0.720 \\
\hline $\begin{array}{l}\text { Signifi- } \\
\text { cance } \\
\text { (P) }\end{array}$ & 0.01 & & 0.01 & & 0.05 & & $\begin{array}{l}<0.05- \\
>0.01\end{array}$ & 0.1 & $0 \cdot 1$ & $\begin{array}{l}<0.05- \\
>0.01\end{array}$ \\
\hline
\end{tabular}

* Rankings of antibody (titre) ratios obtained in GI, MI, and LA tests were scored in each column on a scale 1 (representing the homologous system) to 7 (representing the greatest difference of antibody ratios from homologous system).

$\dagger=$ Total of three values above. 
two strains is indicated by the numerator in each fraction. The greatest degree of antigenic difference between strains was noted for the pairs Ne110-Ni6, Ne110-K and Ni6-7, although differences existed between all strains under study. These observations emphasised the need to compare the reliability of the GI, MI and LA tests in determining antigenic differences. As a first step, the rank order of antibody ratios was made in each column. In all cases, 1 represented the homologous system, and 7 represented the greatest difference from the homologous system. Rankings for the three tests and their totals are listed in table VI. The rank order 1 (total 3) for homologous reactions reflects the greatest serological activity. Clearly, on this basis the tests showed an almost equal capacity to identify homologous strains. Likewise, the rankings reflected a fairly good degree of agreement for all three tests with five of seven strains tested and a lower degree of agreement or discordance with two other strains. This was confirmed by calculations using the concordance coefficient $W$. In all crosses with strains $\mathrm{Ne} 110, \mathrm{Ni6}, \mathrm{Tr} 32, \mathrm{~S} 218$ and 7 the concordance of the test was significant at the $1.0 \%$ to $5.0 \%$ level but with strains Hers and $\mathrm{K}$ only at the $10 \%$ level.

In an attempt to find out which of the tests was responsible for discordance in rank orders, the results with strains Hers and $\mathrm{K}$ were analysed statistically. The findings confirmed previous results because low levels of statistical significance were found between ranked values of two tests: with strain Hers, the $r_{s}$ value for GI-MI was 0.277 , GI-LA 0.491 , and MI-LA 0.465 ; with strain $\mathrm{K}$, the value for GI-MI was 0.638, GI-LA 0.393, and MI-LA 0.269. These values suggest that no method was particularly responsible for the less congruent results between the tests. The discrepant results can be probably attributed to a difference in the reactivity and a lower degree of specificity of the antigenic components present in these two strains.

\section{DisCUSSION}

A comprehensive comparison of $M$. hyorhinis strains seemed necessary because at present there are no internationally-recognised type strains to assist in the serological characterisation of isolates belonging to this species.

The seven strains of $M$. hyorhinis obtained from different geographic areas were found to be serologically interrelated, although antigenically different from one other. The antigenic diversity between strains ranged from slight to profound. Striking differences were shown by the pairs of strains Ne110-K, Ni6-7 and Ne110-Ni6. The species might be regarded, therefore, as a rather broad serotype fit for division into subtypes.

Statistical analysis of the results obtained by the GI, MI and LA tests showed a high level of agreement, suggesting equal efficiency of the techniques for serological differentiation in the case of five of the seven strains tested. No technique proved to be more sensitive for differentiation than another. However, the analysis sometimes revealed substantial differences in results given by individual tests. For example, there was clear inhibition of metabolism of strains 7 and S218 by some heterologous antisera (to Ni6, Tr32, S218 and K) 
STRAIN DIFFERENTIATION OF $M$. HYORHINIS

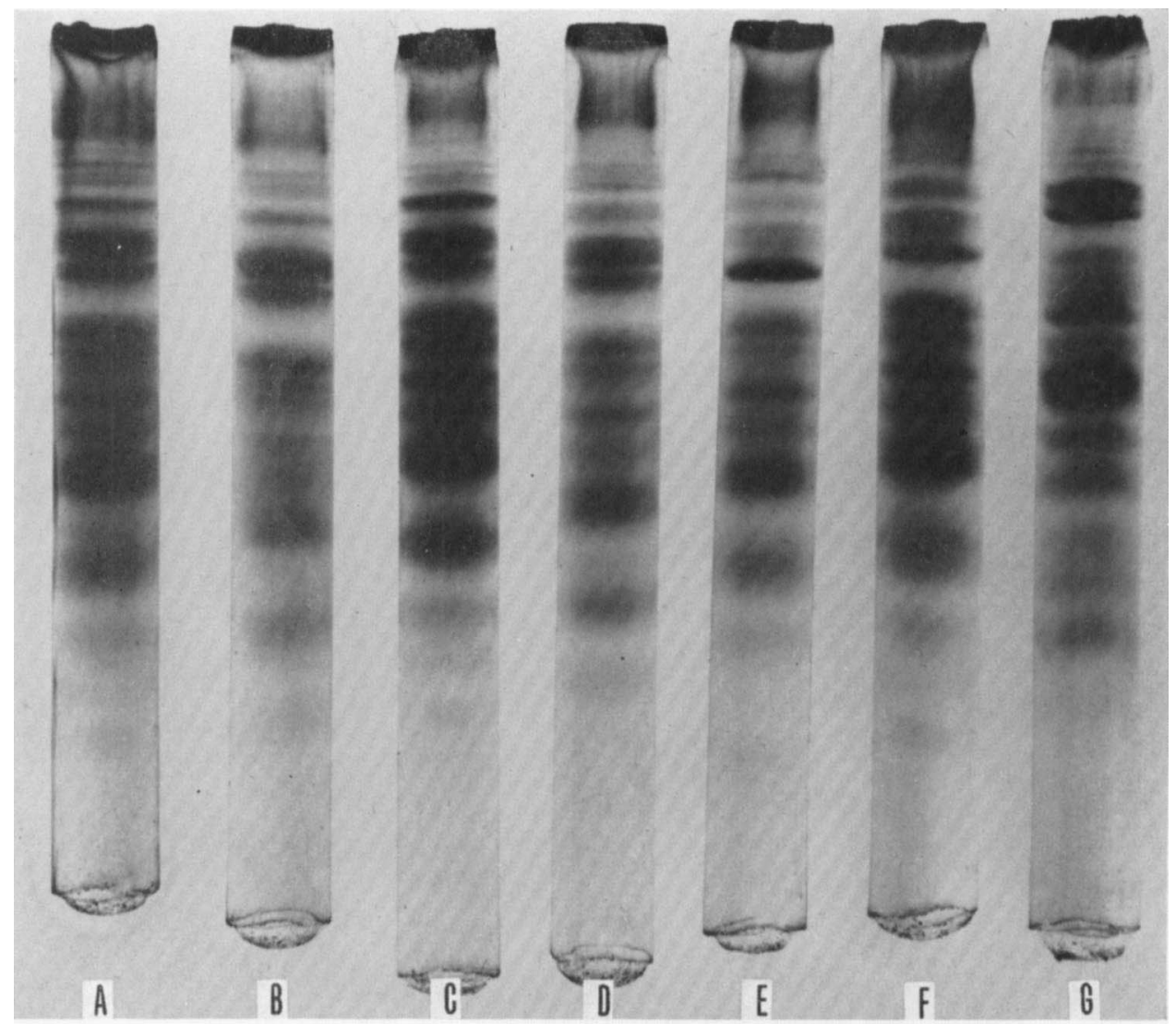

FIGURE.-Polyacrylamide-gel electrophoresis with seven Mycoplasma hyorhinis strains: A $=\operatorname{Tr} 32$; $\mathrm{B}=\mathrm{Ni6} ; \mathrm{C}=\mathrm{Ne110} ; \mathrm{D}=\mathrm{S} 218 ; \mathrm{E}=$ Hers $; \mathrm{F}=\mathrm{K} ; \mathrm{G}=7$. 
whereas no inhibition of growth was detected in the GI test. Such results are in agreement with those mentioned by other workers (Hayflick and Stanbridge, 1967; Purcell, Chanock and Taylor-Robinson, 1969) and suggest that the GI technique might be more useful for the differentiation of some strains. A similar phenomenon of reactivity versus nonreactivity was observed between MI and LA tests. In the latter, strain K reacted negatively or weakly with most of the heterologous antisera whereas it did not do so in MI tests.

Difficulties in studying $M$. hyorhinis by the GI technique were experienced by other investigators (Dinter, Danielsson and Bakos, 1965; Dinter and Taylor-Robinson, 1969) who found that some strains were not inhibited by their homologous rabbit antisera. The phenomenon was ascribed to the occurrence of antibody-insensitive mycoplasmas. We did not encounter a similar problem, rabbit antisera invariably causing inhibition of homologous strains in GI as well as in MI tests. However, it must be pointed out that in an attempt to increase the chance of finding possible serological differences we included in this study only strains that readily showed serological activity with their homologous antisera.

It was reported previously (Purcell et al., 1969; Goiš, Černý and Věžníková, 1970 ) that in MI tests in which 3\% guinea-pig serum was added, all strains of $M$. hyorhinis studied were found to be identical or closely related. By omitting guinea-pig serum in the present experiments, the titres measured by MI were much lower though the specificity of the tests seemed to increase. This conclusion was based on tests, not mentioned here in detail, in which the presence and absence of guinea-pig serum was compared.

Common antigens were demonstrated in seven strains, but it is possible that at least two strains (7 and $\mathrm{K}$ ) possessed minor quantities of some antigenic components and that these could be detected by the LA test. This indicates that the LA test is at least as sensitive as the other methods for the differentiation of $M$. hyorhinis strains, and also shows the need to use more than one technique.

Though considerable serological variation among $M$. hyorhinis strains occurred it was not possible to detect clear-cut differences by polyacrylamide gel electrophoresis. When a strain gave rise to an additional band, it may have done so merely because it produced a greater amount of a particular protein than other strains. The results accord with those seen in a study of T-mycoplasmas (Taylor-Robinson et al., 1971) in which strains from various animal species produced similar band-patterns, although the MI test indicated marked differences.

Finally, emphasis should be laid on the practical implications of the present findings. The relatively low degree of serological relationship among $M$. hyorhinis strains suggests that for diagnostic purposes it might be advisable to use antisera to several antigenically different strains of $M$. hyorhinis.

\section{SUMMARY}

Seven strains of Mycoplasma hyorhinis obtained from different geographic areas were compared by growth-inhibition, metabolism-inhibition and latexagglutination tests. Although serologically interrelated, the strains showed 
differences ranging from slight to profound, and therefore division into subtypes was suggested. Statistical analysis by the coefficient of concordance and by the rank correlation coefficient supported the finding that all three serological methods are probably equally suitable for serological differentiation. Polyacrylamide gel electrophoresis revealed no appreciable differences among the strains.

We wish to thank W. P. Switzer, Z. Dinter and J. Akkermans for providing the cultures of $M$. hyorhinis strains.

\section{REFERENCES}

ARCHETtI, I. AND Horsfall, F. L. JR 1950. Persistent antigenic variation of influenza A viruses after incomplete neutralization in ovo with heterologous immune serum. J. exp. Med., 92, 441.

CLYDE, W. A., JR 1964. Mycoplasma species identification based upon growth inhibition by specific antisera. J. Immun., 92, 958.

DeEB, B. J. AND KENNY, G. E. 1967. Characterization of Mycoplasma pulmonis variants isolated from rabbits. II. Basis for differentiation of antigenic subtypes. J. Bact., 93, 1425.

Dinter, Z., Danielsson, D. and Bakos, K. 1965. Differentiation of porcine mycoplasma strains. J. gen. Microbiol., 41, 77.

DINTER, Z. AND TAYLOR-ROBINSON, D. 1969. Susceptibility and resistance of various strains of Mycoplasma hyorhinis to antisera, polymyxins and low pH values. J. gen. Microbiol., 57, 263.

Gols, M. 1968. Serological response of pigs to infection with mycoplasma. Demonstration of growth and metabolism-inhibiting antibodies in sera of pigs inoculated intranasally with Mycoplasma hyorhinis. Zentbl VetMed. B, 15, 382.

GoIš, M., ČERNÝ, M. AND VĚ̌̃ínovÁ, D. 1970. Relationship between metabolism-inhibiting antibodies and colonial growth of Mycoplasma hyorhinis and other porcine mycoplasma in the presence of rabbit and pig sera. Res. vet. Sci., 11, 161.

HAYFlick, L. AND STANBRIDGe, E. 1967. Isolation and identification of mycoplasma from human clinical materials. Ann. N.Y. Acad. Sci., 143, 608.

Kendall, M. G. 1948. The advanced theory of statistics. 1, 4th ed., London.

LEACH, R. H. AND BUTLER, M. 1966. Comparisons of mycoplasmas associated with human tumors, leukemia, and tissue cultures. J. Bact., 91, 934.

LEMCKE, R. M. 1964. The serological differentiation of mycoplasma strains (pleuropneumonia-like organisms) from various sources. J. Hyg., Camb., 62, 199.

MaLÝ, V. 1957. Význam a užití pơ̌adí ve zdravotnické statistice. Sborn. lék., 59, 155.

MORTON, H. E. 1966. Mycoplasma-latex agglutination reaction. J. Bact., 92, 1196.

Nicol, C. S. AND EDwARD, D. G. ff. 1953. Role of organisms of the pleuropneumonia group in human genital infections. Br.J. vener. Dis., 29, 141.

Purcell, R. H., Wong, D., Chanock, R. M., Taylor-Robinson, D., Canchola, J. and VALDESUSO, J. 1967. Significance of antibody to mycoplasma as measured by metabolicinhibition techniques. Ann. N.Y. Acad. Sci., 143, 664.

Purcell, R. H., Chanock, R. M. and Taylor-Robinson, D. 1969. Serology of the mycoplasmas of man. In The Mycoplasmatales and the L-phase of bacteria, edited by L. Hayflick, New York, p. 221.

RotTeM, S. AND RAZIN, S. 1967. Electrophoretic patterns of membrane proteins of Mycoplasma. J. Bact., 94, 359.

Spearman, C. 1904. Amer. J. Psych., 15, 88. Quoted by G. W. Snedecor \& W. C. Cochran, Statistical methods, 6th ed. 1967, p. 194.

Taylor-Robinson, D., Somerson, N. L., Turner, H. C. And Chanock, R. M. 1963. Serological relationships among human mycoplasmas as shown by complement-fixation and gel diffusion. J. Bact., 85, 1261. 
Taylor-Robinson, D., Purcell, R. H., Wong, D. C. And Chanock, R. M. 1966. A colour test for the measurement of antibody to certain mycoplasma species based upon the inhibition of acid production. J. Hyg., Camb., 64, 91.

TAYLOR-RoBINSON, D. AND BERRY, D. M. 1969. The evaluation of the metabolic-inhibition technique for the study of Mycoplasma gallisepticum. J. gen. Microbiol., 55, 127.

Taylor-Robinson, D., Martin-Bourgon, C., Watanabe, T. and AdDey, J. P. 1971. Isolation of T-mycoplasmas from dogs and squirrel monkeys: biological and serological comparison with those isolated from man and cattle. J. gen. Microbiol., 68, 97. 